\title{
Effective rainfall: a significant parameter to improve understanding of deep-seated rainfall triggering landslide - a simple computation temperature based method applied to Séchilienne unstable slope (French Alps)
}

\author{
A. Vallet, C. Bertrand, and J. Mudry \\ Chrono-Environnement, Université de Franche-Comté, CNRS - UMR6249, 16 route de Gray, \\ 25030 Besançon cedex, France \\ Received: 4 June 2013 - Accepted: 29 June 2013 - Published: 10 July 2013 \\ Correspondence to: A. Vallet (aurelien.vallet@univ-fcomte.fr) \\ Published by Copernicus Publications on behalf of the European Geosciences Union.
}

8945

\begin{abstract}
Pore water pressure, build up by recharge of hydrosystems, is one of the main triggering factors of deep seated landslides. Effective rainfall, which is the part of the rainfall which recharges the aquifer, is a significant parameter. Soil-water balance is an ac5 curate way to estimate effective rainfall. Nevertheless this approach requires evapotranspiration, soil water storage and runoff characterization. Available soil storage and runoff were deduced from field observations whereas evapotranspiration computation is a highly demanding method requiring significant input of meteorological data. Most of the landslide sites used weather stations with limited datasets. A workflow method 10 was developed to compute effective rainfall requiring only temperature and rainfall as inputs. Two solar radiation and five commonly used evapotranspiration equations were tested at Séchilienne. The method was developed to be as general as possible in order to be able to be applied to other landslides. This study demonstrated that, for the Séchilienne unstable slope, the displacement data correlation performance (coefficient 15 of determination) is significantly enhanced with effective rainfall (0.633) compared to results obtained with raw rainfall (0.436) data. The proposed method for estimation of effective rainfall was developed to be sufficiently simple to be used by any non-hydro specialist who intends to characterize the relationship of rainfall to landslide displacements.
\end{abstract}

\section{Introduction}

Effective rainfall corresponds to the water infiltrated through the soil layer and is the actual input signal of the hydrosystem. Patwardhan et al. (1990) showed that Soil-water balance approach is an accurate way to estimate effective rainfall. Effective rainfall computations with Soil-water balance depend mainly on vegetative cover interception, surface runoff, available soil water storage capacity (AWS) and evapotranspiration. Evapotranspiration is the water transpired by vegetation and evaporated from the soil. For 
studies which only took into account the effective rainfall signal, interception was disregarded. Indeed, evapotranspiration is the major factor influencing the effective rainfall signal. Runoff also plays an important role in effective rainfall estimation, especially in mountainous places or heavy rainfall locations.

5 The reference crop evapotranspiration $\left(E T_{0}\right)$, which is the evapotranspiration from a reference grass surface, is used as a standard to evaluate evapotranspiration. It was formerly called potential evapotranspiration. The Penman-Monteith equation for computation of $\mathrm{ET}_{0}$ has been extensively evaluated worldwide and is considered the most widely accepted (Jensen et al., 1990). Following this work, Allen et al. (1998) in

10 the paper no. 56 for the Food and Agriculture Organization of the United Nations (FAO56) developed a modified form of the Penman-Monteith equation (FAO-56 PM) which was adopted as a benchmark equation to estimate $\mathrm{ET}_{0}$ for all climate conditions.

FAO-56 PM requires a large number of weather parameters like wind speed, relative air moisture, temperature and short wave radiation $\left(R_{\mathrm{S}}\right)$. Most of weather stations

15 measure a limited dataset and the data required to use FAO-56 PM are not always available. Additionally, radiation and relative humidity measurements are subject to drift and inaccuracy, which leads to bias in evapotranspiration computation (Samani, 2000; Droogers and Allen, 2002). Most weather stations on landslide study areas record only temperature and rainfall. It is appealing to have methods alternative to FAO-56 PM

20 that utilize empirical or physical evapotranspiration equations using a limited meteorological dataset. In most cases, equations are based on temperature and/or radiation. Moreover, equations were developed to estimate radiation based only on temperature measurements as input (Bristow and Campbell, 1984; Hargreaves and Samani, 1985). Combination of $\mathrm{ET}_{0}$ reduced set and $R_{\mathrm{S}}$ equations enable computing $\mathrm{ET}_{0}$ based only on temperature, which is a widely available parameter, using cost effective materials that are easy to install and maintain without significant sensor drift.

Pore water pressure, build up caused by recharge of hydrosystems, is one of the main triggering factors of deep seated landslides (Noverraz et al., 1998; Bonzanigo et al., 2001; Guglielmi et al., 2005; Bogaard et al., 2007). As the part of rainfall which

8947

effectively recharges the aquifer, effective rainfall is a significant parameter to take into account in understanding deep landslide destabilization triggered by groundwater flow.

The role of rainfall in shallow landslides is well documented. This is not the case for deep landslides. Most of the time, deep seated landslide studies take into account 5 effective rainfall, either without $\mathrm{ET}_{0}$ equations calibration (Binet et al., 2007; Durville et al., 2009; Pisani et al., 2010), or by using indirect methods (Hong et al., 2005; Cappa et al., 2006). Some studies used raw rainfall data as an infiltration input signal (Zêzere et al., 2005). The above approaches can lead to significant error in infiltration estimation and tend to underestimate or overestimate the rainfall trigger. For shallow landslides, 10 effective rainfall can be deduced only by taking into account the runoff data. Because only the shallowest layer is unstable in shallow landslides, large scale groundwater processes are not indicated. The increase of pore water pressure related to rainfall events depends mainly on soil drainage capacity and surface slope (Garel et al., 2012). However, this approach is not suitable for deep seated landslides which involve large scale water catchment and groundwater flow.

In addition, many studies on the Séchilienne unstable slope that related to rainfall trigger used raw rainfall or indirect infiltration estimates (Rochet et al., 1994; Alfonsi, 1997; Meric et al., 2006; Helmstetter and Garambois, 2010). The warning system of Séchilienne hazards prevention, managed by French authority, is also based on raw 20 rainfall. Séchilienne, rainfall trigger studies and the warning system could be significantly enhanced by taking into account effective rainfall instead.

The purpose of this study was to develop a simple method to take into consideration effective rainfall in landslide scientific studies with limited meteorological data on a daily time interval. This method was designed for the hydrology non-specialist. Indeed, land-

25 slide studies involve a wide range of disciplines (seismic, structural geology, modeling, geotechnics, geophysics, and geomechanics...) where scientists do not necessarily have all the tools to compute effective rainfall. 
To demonstrate the contribution of effective rainfall in the understanding of rainfalllandslide relationships a simple correlation approach between effective rainfall and displacement signals was performed.

\section{Material and method}

\section{$5 \quad 2.1$ Study area}

\subsubsection{Context}

The Séchilienne unstable slope is situated near the South-east side of Grenoble, (France). It is located on the right bank of the West to east flowing Romanche River, on the Southern slope of the Mont-Sec/Oeilly Peak Massif. The site is located on the

10 external part of the French Alps, Belledonne crystalline range. The site is composed of vertical north-south foliated mica-schists covered, unconformably, by sedimentary Carboniferous to Liassic deposits, along the massif ridge line, above the unstable zone (Fig. 1). Locally, glacio-fluvial deposits lie over the two previously cited formations. The unstable slope is delineated to the East by a $20^{\circ} \mathrm{N}$ trending major fault zone. Two major

15 wrench faults, striking $140^{\circ} \mathrm{N}$ and $20^{\circ} \mathrm{N}$ moving dextral and sinistral respectively, compartmentalize the disturbed zone. The slope is cut by a heavy network of two conjugate subvertical continuous fracture sets, striking $140^{\circ} \mathrm{N}$ and $50-70^{\circ} \mathrm{N}$ (Vengeon, 1998). The latter divides the slope into numerous subvertical stripe/slice compartments. To a lesser extent, the slope has a large number of subvertical discontinuous fractures, 20 subparallel and slightly dipping toward the valley.

\subsubsection{Deformation mechanism}

The particular importance of the Séchilienne unstable slope is the absence of a significant basal sliding surface. The Séchilienne unstable slope has deep seated progressive deformation controlled by the main discontinuities. The slope is affected by 8949

a toppling movement of the $50-70^{\circ} \mathrm{N}$ striking slices toward the valley coupled with the subsidence of the upper part of the slope near Mount Sec. This mechanism has been described by Vengeon (1998) as an internal breaking mechanism. The landslide velocities smooth over progressively toward the West and the slope foot, whereas the velocity 5 drops abruptly beyond the $20^{\circ} \mathrm{N}$ trending fault zone delimiting the East boundary.

\subsubsection{Hydrogeology and rainfall triggering}

The Guglielmi et al. (2002) hydrogeochemical survey showed that the top sedimentary deposit holds a perched aquifer which recharges a deep saturated zone at the base of the slope, hosted by underlying fractured metamorphic bedrock, with a thick vadose zone above. The groundwater flow is mainly carried through an extended network of fractures with relatively high flow velocities $\left(\mathrm{km} \mathrm{day}^{-1}\right)$. The disturbed zone, about 150 m deep (Le Roux et al., 2011), shows a high hydraulic conductivity in comparison with the bedrock (Vengeon, 1998) and constitutes a perched aquifer. The deformation has caused wide opening of the fractures. The groundwater flow mechanisms,

15 that are responsible for recharge in the disturbed zone, remain open to question. Vengeon (1998) shows that the disturbed zone perched aquifer is recharged by water-level rise of the deep saturated zone whereas Guglielmi et al. (2002) shows that the main recharge originates from the top sedimentary perched aquifer. Variations in pore water pressure originate in the disturbed zone leading to destabilization. As a result, the

20 Séchilienne unstable slope shows a good correlation between antecedent cumulative rainfall and average displacements (Alfonsi, 1997; Rochet et al., 1994). As well, Helmstetter and Garambois (2010) showed a weak but significant correlation between rainfall signals and rock fall micro-seismicity. Instability in the Séchilienne slope is mainly triggered by rainfall events even if other triggers such as earthquakes for example are 25 not insignificant. 


\subsection{Method}

\subsubsection{Effective rainfall computation: soil water balance}

Soil is the first recipient of rainfall and constitutes the first water storage layer. Runoff processes play an important role in effective rainfall computations and, enable split-

5 ting the signal between two parts: (i) water which infiltrates the ground and (ii) water which joins surface drainage networks. Runoff $(R)$ depends mainly on precipitation intensity and related soil drainage capacity, and on slope and vegetation type. The part of the water that infiltrates the soil can then supply the available water storage capacity (AWS), which is the maximum soil water content available for plants. However, the use

10 of a daily measurement period does not allow accurate estimation of rainfall intensity (daily rainfall repartition is unknown). This parameter was therefore not taken into account for defining runoff thresholds based on soil drainage capacity. Instead, runoff coefficient was applied only to the water precipitation left over after AWS was completely fulfilled in order to take into account antecedent soil moisture (affecting soil drainage

15 capacity). Additionally, runoff was applied only for day when precipitations were superior to average (assumed as high intensity). The AWS corresponds to the difference between the soil water content when all free water has been drained through gravity (field capacity) and the moisture content at which plants wilt and die (permanent wilting point). Evapotranspiration withdraws water from plants and soil. $\mathrm{ET}_{0}$ corresponds to

20 the amount of water that could evaporate and transpire from a reference crop surface without restrictions other than atmospheric demand. $\mathrm{ET}_{0}$ is equivalent to the maximum possible water loss of an actively growing reference crop with unlimited water availability. However, field conditions do not always fulfill these requirements, particularly during low water periods, when water supplies are inadequate to support vegetation. It is only

25 when the amount of precipitation (rainfall and snow melt) $(P)$ can supply water to the $\mathrm{ET}_{0}$ process and fulfill AWS that the left-over can infiltrate the aquifer (i.e. effective rainfall - ER). If not, evapotranspiration process can be restrained to null and the AWS is not reached, which leads to the absence of infiltration. The real amount of water which 8951

is evapotranspirated is called actual evapotranspiration $\left(\mathrm{Et}_{\mathrm{a}}\right)$. All the terms $\left(\mathrm{ET}_{0}, \mathrm{AWS}\right.$, $R, P, \mathrm{ER}$, and $\mathrm{Et}_{\mathrm{a}}$ ) are measured in millimeters. For the rest of the paper rainfall will be considered to be the same as precipitation.

The Soil-water balance workflow used for this study to estimate the effective rainfall 5 at a daily interval is shown in Fig. 2.

\subsubsection{Method workflow}

The effective rainfall method workflow (Fig. 3) includes two main steps. The first step involves regional calibration of $\mathrm{ET}_{0}$ and $R_{\mathrm{S}}$ reduced set equations with respect to the benchmark FAO-56 PM equation and direct measurement using reference weather stations measuring all required parameters. The second step uses the Soil-water balance computation of effective rainfall, with calibrated $\mathrm{ET}_{0}$ and $R_{\mathrm{S}}$ equations, AWS and runoff coefficient estimation. Reduced set equations were developed under specific site conditions, and have to be calibrated at a regional scale in order to enhance estimation accuracy (Allen et al., 1994; Tabari and Talaee, 2011; Shahidian et al., 2012). The cal-

15 ibration process involves having representative reference weather stations measuring all required parameters.

\subsubsection{Calculation rate}

The monthly temporal resolution is too low to characterize the displacement ability to react to rainfall events; but it could be sufficient for multi-yearly trending analysis.

20 In addition, it does not allow accounting for short-term groundwater reactivity, which takes part in the slope destabilization mechanism. For a deep-seated landslide involving a basal water saturated zone, the impact of cumulative rainfall is far more significant than rainfall duration or intensity. The hourly rainfall input signal is modified and smoothed over through hydrogeologic processes, depending on the hydrosystem iner-

25 tia and connectivity. For all these reasons this study is based on a daily time step. This choice conditioned the data availability and the weather stations selection. 


\subsection{Data}

\subsubsection{Short wave radiation and evapotranspiration dataset}

MétéoFrance (National French weather network) has a heavy network of weather stations in the region surrounding the Séchilienne landslide. For this study, weather sta-

5 tions were selected upon conditions that (i) all the required parameters to compute $\mathrm{ET}_{0}$ with standard FAO-56 PM (wind speed, relative humidity, temperature, short wave radiation or relative sunshine duration), are measured daily and (ii) they are situated less than 60 kilometers away from the site. Three stations fulfill these requirements: Grenoble Saint-Geoirs, Saint Jean-Saint Nicolas and Saint Michel Maur (Table 1 and 10 Fig. 1).

\subsubsection{Rainfall dataset}

Effective rainfall computation was based on the rainfall at the weather station located at Mont-Sec, only few hundred meters above the top of the disturbed zone (Table 1 and Fig. 1). This station is maintained by EdF (Electricité de France = a French electricity 15 company) and is equipped with both a rain and a snow gauge. This weather station allows the estimation of snow cover and snow melt in water equivalent. Temperatures data recorded are considered not reliable.

\subsubsection{Temperature dataset}

The purpose of this survey is to develop a method based only on temperature. Temperature measurements at Séchilienne are not reliable. In order to reconstruct temperature dataset on site, the two nearest weather stations measuring temperature on a daily basis, named Luitel (maintained by Laboratoire d'étude des Transferts en Hydrogéologie et Environnement - LTHE - and Office National des Forêts - ONF) and Mont Falcon (maintained by CETE Lyon - Centre d'Études Techniques de Lyon) were used (Table 1 25 and Fig. 1).

8953

\subsubsection{Displacement dataset}

The Séchilienne landslide is constantly monitored by numerous displacement stations using a variety of technologies (extensometers, radar, infra-red, inclinometers, GPS). This dense network was progressively implemented by the CETE Lyon since 1985 5 (Duranthon et al., 2003). For this research, the choice fell on extensometers, as they are one of the more reliable displacement recording devices on site, and since they have been installed since the beginning of displacement monitoring. For this study, the extensometer selected, named A16, is located on the most active zone of instability which is also the most reactive zone in relation to rainfall events (Table 1).

\subsection{Equations}

\subsubsection{Radiation equations}

Bristow and Campbell (1984), and Hargreaves and Samani (1985) have each proposed a method to compute short wave radiation $\left(R_{\mathrm{S}}\right)$ based on temperature.

Bristow and Campbell equation $\left(\mathrm{BC} R_{\mathrm{s}}\right)$ :

${ }_{15} \mathrm{BC} R_{\mathrm{s}}=A_{\mathrm{BC}} R_{a}\left[1-\exp \left(-B_{\mathrm{BC}}(\alpha \Delta T)^{C_{\mathrm{BC}}}\right)\right]$

where:

$\Delta T_{\mathrm{BC}}=T_{\max (j)}-\frac{T_{\min (j)}+T_{\min (j+1)}}{2}$.

Hargreaves-Samani equation $\left(\mathrm{HS} R_{\mathrm{S}}\right)$ :

$\mathrm{HS} R_{\mathrm{S}}=A_{\mathrm{HS}} R_{a}\left(\Delta T_{\mathrm{HS}}\right)^{B_{\mathrm{HS}}}$

20 where:

$\Delta T_{\mathrm{HS}}=T_{\max (j)}-T_{\min (j)}$. 
Equation terms for all equations are defined as follows:

$R_{\mathrm{S}}$ short wave solar radiation [ $\mathrm{MJ} \mathrm{m}^{-2} \mathrm{day}^{-1}$ ]

$R_{a}$ extraterrestrial radiation $\left[\mathrm{MJ} \mathrm{m}^{-2}\right.$ day $^{-1}$ ]

$T_{\min }$ minimum air temperature $\left[{ }^{\circ} \mathrm{C}\right]$

${ }_{5} \quad T_{\max }$ maximum air temperature $\left[{ }^{\circ} \mathrm{C}\right]$

$j$ and $j+1$ respectively current day and following day

$A_{\mathrm{BC}}, B_{\mathrm{BC}}, C_{\mathrm{BC}} \mathrm{BC}$ empiric coefficients (to define)

$A_{\mathrm{HS}}, B_{\mathrm{HS}} \mathrm{HS}$ empiric coefficients $\left(A_{\mathrm{HS}}=0.16\right.$ and $\left.B_{\mathrm{HS}}=0.5\right)$

Castellvi (2001) has demonstrated that these two methods show good results on 10 daily intervals. Almorox (2011) has compared the performance of a more extensive list of $R_{\mathrm{S}}$ equations based on temperature which might be more suitable to local conditions at other landslide sites.

\subsubsection{Evapotranspiration equations}

Several reference crop evapotranspiration $\left(\mathrm{ET}_{0}\right)$ methods, using a reduced dataset 15 in comparison to FAO-56 PM, have been developed worldwide. Only a few are commonly used and have been reviewed by the scientific community. This is the case with the five $\mathrm{ET}_{0}$ methods selected for this study, which have shown good performance from using daily to the weekly time periods (Trajkovic, 2005; Yoder et al., 2005; Alexandris et al., 2008; Tabari et al., 2011; Shahidian et al., 2012). The five $\mathrm{ET}_{0}$ methods include five radiation/temperature based methods, Makkink (1957), Turc (1961), and Priestley-Taylor (1972), Hargreaves-Samani (1985), and the Penman-Monteith reduced set equation (Allen et al., 1998). $\mathrm{ET}_{0}$ matches with the evaporation rate of a hypothetical crop which can be considered as an extensive and uniform surface of green grass (Allen et al., 1998). Specific crop evapotranspiration $\left(E T_{c}\right)$ is estimated by applying a crop specific coefficient $\left(k_{\mathrm{c}}\right)$ to $\mathrm{ET}_{0}$ (i.e. $\mathrm{ET}_{\mathrm{c}}=\mathrm{ET}_{0} \times k_{\mathrm{c}}$ ). The crop coefficient is widely used for irrigation scheduling, and in agriculture generally, where accurate evaporation estimation is required and spatial distribution of vegetation types are easy to characterize. However, this study was only concerned with the effective rainfall sig8955

nal, in comparison to the rainfall one. No water budget computation or spatialization endeavor was undertaken. These are the reasons $\mathrm{ET}_{0}$ is considered equal to $\mathrm{ET}_{\mathrm{C}}$ for this study.

Because of the two $R_{\mathrm{S}}$ temperature based methods, the five $\mathrm{ET}_{0}$ methods selected 5 above can be computed only with temperature. Some $\mathrm{ET}_{0}$ reduced set equations used $R_{\mathrm{n}}$, instead of $R_{\mathrm{S}}$, which can be deducted from $R_{\mathrm{S}}$ with the Penman-Monteith reduced set equation assumptions (Allen et al., 1998).

FAO-56 PM equation:

FAO-56 PM ET $0=\frac{0.408 \Delta\left(R_{\mathrm{n}}-G\right)+\gamma_{\overline{T_{\text {avg }}+273}} u_{2}\left(e_{\mathrm{s}}-e_{\mathrm{a}}\right)}{\Delta+\gamma\left(1+0.34 u_{2}\right)}$.

10 Hargreaves-Samani equation ( $\mathrm{HSET}_{0}$ ):

HSET $_{0}=0.0135 \cdot 0.408 R_{\mathrm{s}}\left(T_{\text {avg }}+17.8\right)$.

The unit conversion factor 0.408 was added to the $\mathrm{HSET}_{0}$ formula in order to compute $\mathrm{ET}_{0}$ in mm day ${ }^{-1}$ with $R_{\mathrm{S}}$ in $\mathrm{MJm}^{-2}$ day $^{-1}$.

Turc equation (Turc $\mathrm{ET}_{0}$ ):

15 For $\mathrm{RH}>50 \% \operatorname{Turc}_{0}=0.01333 \frac{T_{\text {avg }}}{T_{\text {avg }}+15}\left(23.9001 R_{\mathrm{s}}+50\right)$

For $\mathrm{RH}<50 \%$ Turc $\mathrm{ET}_{0}=0.01333 \frac{T_{\text {avg }}}{T_{\text {avg }}+15}\left(23.9001 R_{\mathrm{s}}+50\right)\left(1+\frac{50-\mathrm{RH}}{70}\right)$.

Equation (7) was used as average of relative humidity of the nearby mountain weather stations. For Séchilienne, the result was higher than $50 \%$ (Chamrousse, 70\%; Saint 20 Michel Maur, $66 \%$; Saint Jean-Saint Nicolas, $66 \%)$.

Priestley-Taylor equation (PTET $)$ :

$\mathrm{PTET}_{0}=1.26 \frac{\Delta}{\Delta+\gamma}\left(R_{\mathrm{n}}-G\right)$. 
Makkink equation ( $\left.\mathrm{MET}_{0}\right)$ :

$\mathrm{MET}_{0}=0.61 \frac{\Delta}{(\Delta+\gamma)} \frac{R_{\mathrm{s}}}{2.45}-0.012$

Penman-Monteith reduced set equation $\left(\mathrm{PM}_{\text {red }} \mathrm{ET}_{0}\right)$ :

Identical to PM FAO-56 equation (Eq. 5) but humidity and wind speed are estimated 5 according to FAO-56 guidelines with the following assumption (Allen et al., 1998):

$e_{\mathrm{a}}=e^{0}\left(T_{\min }\right)=0.611 \exp \left(\frac{17.27 T_{\min }}{T_{\min }+237.3}\right)$.

Wind speed was fixed at $1.5 \mathrm{~m} \mathrm{~s}^{-1}$ at $2 \mathrm{~m}$ height $\left(2 \mathrm{~m} \mathrm{~s}^{-1}\right.$ by default), which is the rounding average of the nearby mountain weather stations (Chamrousse, $2.33 \mathrm{~m} \mathrm{~s}^{-1}$; Saint Michel Maur, $0.95 \mathrm{~m} \mathrm{~s}^{-1}$; Saint Jean-Saint Nicolas, $1.26 \mathrm{~m} \mathrm{~s}^{-1}$ ).

10 Equation terms for all equations are defined as follow:

$\mathrm{ET}_{0}$ reference crop evapotranspiration $\left[\mathrm{mm} \mathrm{day}^{-1}\right.$ ]

$\Delta$ slope vapour pressure curve $\left[\mathrm{kPa}^{\circ} \mathrm{C}^{-1}\right]$

$R_{\mathrm{n}}$ net radiation $\left[\mathrm{MJ} \mathrm{m}^{-2}\right.$ day $^{-1}$ ]

$R_{\mathrm{S}}$ short wave radiation $\left[\mathrm{MJ} \mathrm{m}^{-2}\right.$ day $^{-1}$ ]

$15 G$ soil heat flux density $\left[\mathrm{MJ} \mathrm{m}^{-2}\right.$ day $^{-1}$ ]

$\gamma$ psychrometric constant $\left[\mathrm{kPa}^{\circ} \mathrm{C}^{-1}\right]$

$T_{\text {avg }}$ average air temperature at $2 \mathrm{~m}$ height $\left[{ }^{\circ} \mathrm{C}\right]$

$T_{\min }$ minimum air temperature at $2 \mathrm{~m}$ height $\left[{ }^{\circ} \mathrm{C}\right]$

$T_{\max }$ maximum air temperature at $2 \mathrm{~m}$ height $\left[{ }^{\circ} \mathrm{C}\right]$

$20 \quad u_{2}$ wind speed at $2 \mathrm{~m}$ height $\left[\mathrm{m} \mathrm{s}^{-1}\right]$

$e_{\mathrm{s}}$ saturation vapour pressure $[\mathrm{kPa}]$

$e_{\mathrm{a}}$ actual vapour pressure [kPa]

$\mathrm{RH}$ relative humidity [\%]

For this study, calculation of the different previously cited terms follows the FAO-

56 guideline. The foregoing $\mathrm{ET}_{0}$ equations were developed for irrigation scheduling, 8957

where the scope of application involves positive temperature (plants water supply during spring-summer growing period). However, on mountainous sites, winter temperatures are very often negative, and $\mathrm{ET}_{0}$ empirical equations can compute negative $\mathrm{ET}_{0}$ values, which don't have physical meaning. This is why negative $\mathrm{ET}_{0}$ computed values 5 were set to zero for this study.

\subsection{Regional equation calibration}

Regional equation calibration was performed using nearby weather stations measuring required data (i.e. Saint Geoirs, Saint Michel Maur and Saint Jean-Saint Nicolas weather stations). The dataset number used at each weather station was unique. To account for the three weather station locations with the same weight, calibration coefficients adjustment and performance assessment were determined at each weather station first (local scale) and then the average of the three sites was used as regional reference (regional scale).

\subsubsection{Radiation equations calibration}

15 The calibration of the $R_{\mathrm{s}}$ equation was performed using the following modified form from the original Eqs. (1) and (3):

Bristow and Campbell modified equation $\left(\mathrm{BC}_{\bmod } R_{\mathrm{s}}\right)$ :

$\mathrm{BC}_{\text {mod }} R_{\mathrm{s}}=A_{\mathrm{BC}} R_{a}\left[1-\exp \left(-B_{\mathrm{BC}}(\alpha \Delta T)^{C_{\mathrm{BC}}}\right)\right]+D_{\mathrm{BC}}$

Hargreaves-Samani modified equation $\left(\mathrm{HS}_{\bmod } R_{\mathrm{s}}\right)$ :

20

$\mathrm{HS}_{\mathrm{mod}} R_{\mathrm{s}}=A_{\mathrm{HS}} R_{a}(\alpha \Delta T)^{B_{\mathrm{HS}}}+C_{\mathrm{HS}}$ 
where

$A_{\mathrm{BC}}, B_{\mathrm{BC}}, C_{\mathrm{BC}}, D_{\mathrm{BC}} \mathrm{BC}$ regional calibration coefficients

$A_{\mathrm{HS}}, B_{\mathrm{HS}}, C_{\mathrm{HS}} \mathrm{HS}$ regional calibration coefficients

$\alpha$ cloud cover adjustment factor

$5 \quad$ An intercept was added to both $R_{\mathrm{S}}$ equations in case of a shift in the $R_{\mathrm{S}}$ estimation from the original equation for the Séchilienne site. Both equations already have an empirical slope coefficient. Bristow-Campbell coefficients had to be evaluated whereas Hargreaves-Samani equation coefficients were already estimated with numerical values. However, Trajkovic (2007) showed that regional calibration of the Hargreaves

10 equation (combine $\mathrm{ET}_{0}$ and $R_{\mathrm{S}}$ ) is significantly improved by coefficient adjustments rather than by linear regression. Therefore, all the $\mathrm{HS}_{\text {mod }} R_{\mathrm{s}}$ coefficients were adjusted.

Furthermore, a cloud cover adjustment factor $\alpha$ (ranging from 0 and 1) was applied to $\Delta T$ as under cloudy conditions $\Delta T$ yield larger than expected compared to incoming radiation (Bristow and Campbell, 1984). This correction is not required but improves the

15 estimation. This coefficient was applied for the two first rain event day as temperature and $R_{\mathrm{s}}$ get equilibrated beyond extended period of rainfall. As well if $\Delta T$ on the day before rain event $\left(\Delta T_{j-1}\right)$ was less than $\Delta T_{j-2}$ by more than $2^{\circ} \mathrm{C}$, the coefficient was also applied assuming cloudy cover was already significant. For the other days, $\alpha$ was set to 1.

20 Adjustment of coefficients (including cloud cover adjustment) for the $R_{\mathrm{S}}$ regional calibration was nonlinear (i.e. not type $Y=a x+b$ ). To adjust the calibration coefficients, an iterative algorithm was used to optimize the Eq. (14) to one.

$\frac{\sum_{i=1}^{m}\left(r_{m}^{2}-\mathrm{RE}_{m}\right)}{m} \rightarrow 1$

where $m$ is the number of weather stations used for calibration, $R^{2}$ (Eq. 17) is the 25 coefficient of determination and RE (Eq. 19) is the relative error at each weather station.

8959

\subsubsection{Evapotranspiration equations calibration}

Previously cited $\mathrm{ET}_{0}$ equations were developed under specific climatic conditions. FAO56 PM calculated data at Saint Geoirs, Saint Jean-Saint Nicolas and Saint Michel Maur, were used as benchmarks to calibrate $\mathrm{ET}_{0}$ reduced set equations, in order to take into

5 account Séchilienne climatic conditions and increase the equations' accuracy. Linear regression equations were defined for each equation and for each station with the benchmark data as dependent variables and the data from calibrated equations as explanatory variables. The slope $a$ and the intercept $b$, of the best fit regression line, were then used as regional calibration coefficients:

$\mathrm{ET}_{0 \mathrm{FAO}-56 \mathrm{PM}}=a \mathrm{ET}_{0 \text { method }}+b$

where $\mathrm{ET}_{0 \mathrm{FAO}-56 \mathrm{PM}}$ is the reference crop evapotranspiration; $\mathrm{ET}_{0 \text { method }}$ is one of the five reduced set equations tested in this study; $a$ and $b$ are the calibration coefficients.

This method has been widely used to calibrate $\mathrm{ET}_{0}$ reduced-set equations (Allen et al., 1994; Trajkovic, 2005; Shahidian et al., 2012).

15 Reduced-set $\mathrm{ET}_{0}$ equations do not take into account wind speed variation. Wind by removing satured air from the boundary layer, increases evapotranspiration (Shahidian et al., 2012). Many studies show the influence of wind speed on reduced set $\mathrm{ET}_{0}$ equation performance and therefore on calibration (Itenfisu et al., 2003; Trajkovic, 2005; Igbadun et al., 2006; Trajkovic and Stojnic, 2007). For this study, days with wind speed 20 above $3.5 \mathrm{~m} \mathrm{~s}^{-1}$ at $2 \mathrm{~m}$ height were disregard for the calibration $(9,1$ and $3 \%$ for respective dataset of Saint Geoirs, Saint Jean-Saint Nicolas and Saint Michel Maur).

Saint Michel Maur weather station does not measure $R_{\mathrm{S}}$, however it can be calculated with the Angström formula using sunshine duration data recorded at the station (FAO-56 guidelines):

${ }_{25} \quad R_{\mathrm{s}}=\left(a_{\mathrm{s}}+b_{\mathrm{s}} \frac{n}{N}\right) R_{a}$ 
where:

$R_{\mathrm{s}}$ short wave radiation $\left[\mathrm{MJ} \mathrm{m}^{-2}\right.$ day $^{-1}$ ]

$a_{\mathrm{s}}+b_{\mathrm{s}}$ fraction of extraterrestrial radiation reaching the earth on clear days by default

$a_{\mathrm{s}}=0.25$ and $b_{\mathrm{s}}=0.5$ (without calibration)

$5 \quad n$ actual duration of sunshine $[\mathrm{h}]$

$N$ maximum possible duration of sunshine $[\mathrm{h}]$

$R_{a}$ extraterrestrial radiation $\left[\mathrm{MJ} \mathrm{m}^{-2}\right.$ day $^{-1}$ ]

$a_{\mathrm{S}}$ and $b_{\mathrm{S}}$ were estimated (respectively 0.232 and 0.574 ) using nearby weather stations measuring actual duration of sunshine and short wave radiation (i.e. Saint Geoirs 0 and Saint Jean-Saint Nicolas weather stations).

\title{
2.5.3 Performance assessment of regional equations
}

The performance assessment and ranking for each of the regional calibrated equation (i.e. with all calibration coefficients adjusted) were evaluated with the $R^{2}, a$ and $b$ coefficients from the linear regression, and RE.

$$
\begin{aligned}
& R^{2}=\left(\frac{\sum_{i=1}^{n}\left(P_{i}-\bar{P}\right)\left(O_{i}-\bar{O}\right)}{\sqrt{\sum_{i=1}^{n}\left(P_{i}-\bar{P}\right)^{2} \sum_{i=1}^{n}\left(O_{i}-\bar{O}\right)^{2}}}\right)^{2} \\
& \text { Root mean square error (RMSE) }=\sqrt{\frac{\sum_{i=1}^{n}\left(P_{i}-O_{i}\right)^{2}}{n}} \\
& \operatorname{RE}=\frac{\text { RMSE }}{\bar{O}}
\end{aligned}
$$

Equation terms are defined as follow:

$P_{i}$ estimated data/explanatory variable

$O_{i}$ observed data/dependent variable

\begin{abstract}
$n$ data number
$\bar{P}$ average of the entire estimated dataset/explanatory variable

$\bar{O}$ average of the entire observed dataset/dependent variable
\end{abstract}

\subsection{Available water storage estimation and runoff coefficient}

5 AWS capacity is dependent on the vegetation surface type, as root zone extension and permanent wilting point are variable from one plant to another. As well, AWS varies according to the soil texture and thickness, which primarily rely on geology formation and vegetation type. For all these reasons, on natural water catchment (i.e. comparatively to cultivated catchment), and especially in mountainous sites, AWS shows high 10 spatial variability. Furthermore, AWS also varies over time as water demand depends on growing plant activities.

A current way to estimate AWS is to use a spring with a well defined water catchment representative of the study area. A water budget computation, at spring scale, would allow deducing AWS with rainfall as input and spring flow as output. However, there were no such springs on the site of Séchilienne.

Dynamic part of runoff is computed in the Soil-water balance model (conditional statement). However, surface runoff coefficient magnitude need to be estimated and depends mainly on slope magnitude and vegetation.

For this study no attempt of spatialization of AWS and runoff coefficient was un20 dertaken. They were assumed to be uniform spatially on the water catchment, and constant overtime. However, a spatial approach has been followed in order to estimate there order of magnitude.

On the Séchilienne watershed, there are three main geology types (mica-schist bedrock, sedimentary cover and superficial formations) and two main vegetation types

25 (grass/forest) which lead to six main kinds of combined geology/vegetation types. For each geology/vegetation types, one auger hole was drilled (Fig. 1) at a representative location. An order of magnitude of AWS was deduced from soil texture and depth extent 
from auger hole cores, thanks to pedotransfer function (Bruand et al., 2004; Jamagne et al., 1977).

The runoff coefficient was deduced from vegetation type and slope analysis on the Séchilienne landslide watershed (Sautier, 1984), estimated respectively with aerial

5 photography and with a digital elevation model of $50 \mathrm{~m}$ resolution.

An additional type, geomorphological based and common of the two previous categories, was added to take into account preferential infiltration structures (PIS) as sinkholes, crevasses, reverse slope areas, bare ground and any topographical depressions which gather precipitations. For this type, AWS and runoff were assumed null. Field

10 observations, aerial photography and geology map were used to assess surface proportion of it.

Both AWS and runoff, deduced for the different types were then integrated across the watershed, according to type surface proportion.

\subsection{Mont Sec temperature estimation}

15 The Mont Sec weather station was used for effective rainfall computation but temperatures were not measured and had to be estimated.

The higher the elevation, the lower the air pressure. The decrease in air density leads to a drop-off of air temperature. Air temperature then can be related to elevation.

In order to compute a local air temperature gradient two weather stations surrounding

20 Séchilienne site were used (weather stations of Luitel and Mont Falcon). The Luitel weather station has similar climatic conditions as the Mont Sec and has only $200 \mathrm{~m}$ elevation difference. Mont Falcon is located on the opposite slope of Séchilienne at the bottom of the Valley. A small correction to take into account elevation difference would be sufficient to estimate temperature at Mont Sec from Luitel. However, in order

25 to maximize common interval lengths of temperature with displacements time series (1994 to now), Mont Falcon weather stations (2004 to now) was selected as reference to estimate temperature at Mont Sec rather than Luitel (2006 to now).

8963

To define the local air temperature gradient in relation to elevation and to calibrate the following equations, Mont Falcon temperatures (minimum and maximum) were used to estimate the temperatures at Luitel in relation to elevation, on their common data interval:

$5 \quad T_{\text {(Station) }}=a T_{\text {(Falcon) }}+b$ Grad $_{\text {elevation }}$

$\operatorname{Grad}_{\text {elevation }}=$ Elevation $_{\text {Falcon }}-$ Elevation $_{\text {Station }}$

where $a$ and $b$ are the regional calibration coefficients, elevation is in meters, Falcon stands for temperature measured at Mont Falcon, station for temperature station target

10 (Luitel for the calibration) and the others terms were defined previously. Linear regression was performed to adjust the $a$ and $b$ coefficients, then the $b$ coefficient was divided by the elevation gradient of the two stations used.

\subsection{Correlation displacement - effective rainfall}

\subsubsection{Displacement signal}

15 Long term displacement monitoring, of the most active zone of the Séchilienne landslide, shows that displacement rate has significantly increased overtime. The same applies for the displacement amplitude (Fig. 6a). This can be the result either a deterioration of superficial rock mechanical properties, a change of behavior in groundwater hydrodynamics, or both, due to long term repetitive deformation (Rutqvist and

20 Stephansson, 2003). It means that for the same amount of rainfall, the displacement rate and amplitude are not the same overtime. The purpose of this paper is not to characterize landslide behavior, but to relate rainfall input signals to displacements. In terms of time series analysis, displacement data series show a trend in amplitude variance as well as mean displacement. In order to be able to compare rainfall signal with dis-

25 placement signal on long term, displacement data trends was removed (detrending). In fact, the observed trend is not dependent on rainfall, but finds its origin in modification 
of landslide mechanical properties. Trend was defined by curve fitting of a fourth order polynomial. Removal of trend was performed with the multiplicative method (i.e. time series is divided by the trend) which result in a unitless time series with both variance and mean trend removed.

\section{2.8.2 Cumulative rainfall/effective rainfall signal}

Antecedent cumulative rainfall $(P)$ and antecedent cumulative effective rainfall (ER) was used to compute the correlation with landslide displacement. A decreasing factor was applied to the sum as an old rainfall event displays less impact than the most recent on groundwater hydrodynamic due to drainage process (Canuti et al., 1985).

10 Three different types of decreasing sums were developed for this study:

Decreasing Sum $=\sum_{i=1}^{n} \frac{P_{i+\beta}}{1+\alpha(i-1)}$

Square Decreasing Sum $=\sum_{i=1}^{n} \frac{P_{i+\beta}}{1+(\alpha(i-1))^{2}}$

Exponential Decreasing Sum $=\sum_{i=1}^{n} \frac{P_{i+\beta}}{\exp (\alpha(i-1))}$

15 where:

$n$ cumulative period (day)

$i$-th day

$P_{i}$ effective rainfall or rainfall at the ith day $(\mathrm{mm})$

$\alpha$ decreasing factor

$20 \quad \beta$ shifting factor (day)

The denominator constitutes, for the three methods, the weighting factor applied to the cumulative sum. For $\alpha$ equaling zero, the three previous methods match with a simple sum of cumulative rainfall.

$$
8965
$$

\subsubsection{Correlation method}

Linear regression between cumulative effective rainfall and displacement and between cumulative rainfall and displacement were performed for each equation, with $n$ ranging from 1 to 250 days (increment 1 day), $\alpha$ ranging from 0 to 0.5 (increment 0.001 ) and

$5 \beta$ ranging from 1 to 10 days (increment 1 ). An iterative algorithm was used to find the best solution based on $R^{2}$ to assess the goodness of fit.

Iterative algorithm and $R^{2}$ based performance, can lead to long cumulative periods associated with really low weighting factor. Indeed, dozens of days can be added, with weighting inferior to one hundredth, only to improve correlation performance

$10\left(R^{2}\right)$ of some thousandths. Increasing period and decrease weighting play the role of a smoothing function. This correlation improvement is rather explained by randomness/noise smoothing of input signal than physical meaning. To avoid that, a $R^{2}$ tolerance of 0.001 for the best correlation performance was implemented. The computation with a performance ranging in the tolerance window and having the minimum cumula15 tive period $(n)$ was selected as the best correlation.

In addition, infiltration can be assumed to be spatially heterogeneous on Séchilienne water catchment. Indeed, in fractured rock context the groundwater flow is mainly supported by an anisotropic fracture network. As a result some area of the water catchment will have higher contribution than other to water supply of the Séchilienne perched aquifer. To take into account this fact, a sensitive analysis was performed. The previous correlation computation for effective rainfall was repeated for different watershed proportion of the preferential infiltration structures (PIS) type (with null AWS and surface runoff). This type is linked to the geology structures. Variations of PIS proportion lead to change of AWS and runoff coefficient, firstly estimated with the assumption of 25 a spatial homogeneous infiltration on the whole watershed.

The relationship between effective rainfall and displacement was only performed in this study to demonstrate the contribution of effective rainfall in landslide understanding. So the best fitting linear regression for rainfall, effective rainfall with homogenous and 
heterogeneous spatial infiltration were compared. This comparison allowed assessing input signal correlation performance with displacement.

\section{Results and discussion}

\subsection{Radiation equations}

5 Data used for calibration were from 8 July 2009 to 1 January 2012 at Grenoble Saint Geoirs weather stations (907 data) and from 1 January 2004 to 1 January 2012 for both Saint Jean-Saint Nicolas (2876 data) and Saint Michel Maur (2864 data) weather stations. Both calibrated methods showed similar and good results in regard to $R_{\mathrm{S}}$ measured at the weather stations (Table 2). The $\mathrm{BC} R_{\mathrm{S}}$ method was selected as it 10 showed slightly superior performance.

\subsection{Evapotranspiration equations}

The same dataset extension as $R_{\mathrm{S}}$ calibration was used for $\mathrm{ET}_{0}$ methods regional calibration but with extreme wind days removed (Grenoble Saint Geoirs (829 data); Saint Jean-Saint Nicolas (2844 data) and Saint Michel Maur (2779 data)). $\mathrm{BC}_{\mathrm{mod}} R_{\mathrm{s}}$ cali-

15 brated method calibrated above was used to compute $R_{\mathrm{S}}$ input data of the five $\mathrm{ET}_{0}$ reduced set equations. Overall, all the $\mathrm{ET}_{0}$ equations tested showed good result and were all suitable, with regional calibration, for the Séchilienne site (Table 3). $\mathrm{PM}_{\mathrm{red}} \mathrm{ET}_{0}$ showed the best estimation performance. $\mathrm{PTET}_{0}$ and $\mathrm{HSET}_{0}$ showed very good performance. Turc $\mathrm{ET}_{0}$ and $\mathrm{MET}_{0}$ show slightly inferior performance but they were very

20 acceptable. PTET 0 , Turc $\mathrm{ET}_{0}$ and $\mathrm{MET}_{0} a$ and $b$ coefficients showed that regional calibration is required. On the other hand, $\mathrm{PM}_{\text {red }} \mathrm{ET}_{0}$ and $\mathrm{HS} \mathrm{ET}_{0} a$ and $b$ coefficients showed that these methods can perform well even without regional calibration.

Therefore, $\mathrm{PM}_{\text {red }} \mathrm{ET}_{0}$ was selected to compute $\mathrm{ET}_{0}$ for the Séchilienne site for this study (best performance and almost no calibration needed). Figure 4 compares the results at each station of the selected equation versus the benchmark FAO-56 PM 8967

computation. $\mathrm{PM}_{\text {red }} \mathrm{ET}_{0}$ and $\mathrm{PTET}_{0}$ involve complex computation and multiple calculation steps as $R_{\mathrm{n}}$ estimation. Although, $\mathrm{HS} \mathrm{ET}_{0}$ showed inferior performance than the two previous cited methods, it is considerably effortless to implement. Indeed, $\mathrm{HS} \mathrm{ET}_{0}$ is one of the more simple equation to use from the five methods tested. An alterna5 tive for effortless estimation of $\mathrm{ET}_{0}$ on Séchilienne would be to use the calibrated $\mathrm{HS}$ $\mathrm{ET}_{0}$ method. In addition, $\mathrm{HS} \mathrm{ET}_{0}$ method showed very acceptable performance to be used for simple $\mathrm{ET}_{0}$ estimation with no calibration in the surrounding environment of Séchilienne.

\subsection{Available water storage estimation and runoff coefficient}

Orders of magnitude of AWS were deduced from auger holes, thanks to soil texture characterization and pedotransfer function for each geology/vegetation type (Table 4). The runoff coefficients were also estimated for each slope/vegetation type (Table 4).

Runoff coefficients and AWS were then computed, according to type respective watershed proportions, for the whole watershed with results of $135 \mathrm{~mm}( \pm 10 \mathrm{~mm})$ and $1514 \%$, respectively (Table 4 ).

Although AWS and runoff estimations are either based on punctual direct observations or either on indirect methods, it is sufficiently accurate for effective rainfall signal estimation.

For other sites, in addition to auger holes and slope investigation, any available infor-

20 mation, qualitative or quantitative, relative to infiltration should be used to characterize AWS and runoff.

\subsection{Mont Sec temperature estimation}

Estimation of local air temperature gradient show very good performance with $R^{2}$ equals to 0.839 and 0.8495 and RMSE equals to 2.62 and 3.31 respectively for minimum and maximum daily temperature calibration. Equation 25 and 26 were used to estimate temperatures at Mont Sec with Mont Falcon measured temperatures. Data 
extension used for temperature calibration was from 6 July 2006 to 2 July 2012 (2127 data), common interval of the two weather stations used (Mont Falcon, Luitel). Local air temperature gradient estimated is about $0.8^{\circ} \mathrm{C}$ per $100 \mathrm{~m}$ of elevation (average of two equations).

$5 \quad T_{\min (\text { Mont Sec })}=0.866 T_{\min (\text { Falcon })}-0.010 \cdot 728$

$T_{\max (\text { Mont Sec })}=0.947 T_{\max (\text { Falcon })}-0.006 \cdot 728$

The absence of temperature at the Mont Sec weather station increases the uncertainties in the estimation of $R_{\mathrm{S}}$ and $\mathrm{ET}_{0}$ equations.

\subsection{Effective rainfall computation}

Final $\mathrm{ET}_{0}$ equation calibrated (Eq. 27) used on Séchilienne site is the $\mathrm{PM}_{\text {red }} \mathrm{ET}_{0}$ (Eq. $5)$ involving multiple step computation and actual vapour pressure $\left(e_{\mathrm{a}}\right)$ estimation with FAO-56 assumption. Wind speed was set to $1.5 \mathrm{~m} \mathrm{~s}^{-1}$ and $R_{\mathrm{n}}$ was deduced from the calibrated $\mathrm{BC}_{\text {mod }} R_{\mathrm{S}}$ method (Eq. 28) with $\alpha$ either 0.79 or either 1. Effective rainfall was 15 then estimated with an AWS of $135 \mathrm{~mm}$.

$$
\begin{aligned}
& \mathrm{ET}_{0 \text { Séch }}=0.994 \frac{0.408 \Delta\left(R_{n}-0\right)+\gamma \frac{900}{T_{\text {avg }}+273} 1.5\left(e_{\mathrm{s}}-e_{\mathrm{a}}\right)}{\Delta+\gamma(1+0.34 \cdot 1.5)}+0.013 \\
& B C_{\text {mod }} R_{\mathrm{s}}=0.669 R_{a}\left[1-\exp \left(-0.010(\alpha \Delta T)^{2.056}\right)\right]+1.733
\end{aligned}
$$

However, for effortless $\mathrm{ET}_{0}$ calculation, the following Eq. (29) can be used on Séchilienne with lower estimation performance (combination of calibrated $\mathrm{BC}_{\text {mod }} R_{\mathrm{S}}$ and calibrated $\mathrm{HS} \mathrm{ET}_{0}$ ):

$$
\begin{aligned}
\mathrm{ET}_{0}= & 0.920 \cdot 0.0135 \cdot 0.408\left(0.669 R_{a}\left[1-\exp \left(-0.010(\alpha \Delta T)^{2.056}\right)\right]+1.733\right) \\
& \cdot\left(T_{\text {avg }}+17.8\right)+0.130 . \\
& 8969
\end{aligned}
$$

Equation terms were described in respective equation references. Although dataset extension allowed to compute effective rainfall since 17 September 2004, it has been chosen to start to take into account computation results from 1 November 2004 in order that AWS get equilibrated in the Soil-water balance process (no edge effects due 5 to initial conditions).

Figure 5 shows the results of the effective rainfall computation and the comparison with the raw rainfall signal. The effective rainfall signal differs significantly from the rainfall signal, essentially during summer and surrounding months when $\mathrm{ET}_{0}$ is important. Indeed, the first rainfall events after a dry period do not reach the aquifer until AWS is

10 full, which can explain why some summer rain periods are not correlated to unstable events on the landslide.

\subsection{Displacement detrending}

A fourth order polynomial regression, applied to the A16 displacement time series (Fig. 6a), accounts for the trend. Equation of trend has the following form:

${ }_{15} y=3.6789 \times 10^{-14} x^{4}-5.5384 \times 10^{-9} x^{3}+3.1263 \times 10^{-4} x^{2}-7.8423 x+7.3759 \times 10^{4}$.

The detrending was performed on a larger interval (1 January 1999 to 28 February 2012) than the one used for rainfall-displacement correlation (1 November 2004 to 30 November 2011) which was restricted by the effective rainfall dataset and reduced on purpose by three months for respectively inferior and superior bounds. Indeed, trend characterization is a statistical process which is enhanced by increasing data amounts taken into account. In addition, using larger framing interval allow reducing edge effects. Result of trend removal by multiplicative method is shown in Fig. 6b. The detrend displacement data are then used for the correlation with rainfall and effective rainfall. 


\subsection{Correlation rainfall-displacement}

Data extension for rainfall-displacement correlation was from 15 July 2005 to 30 November 2011 (2324 data), common interval of A16 extensometers and Mont Sec weather station.

5 According to AWS estimation of $135 \mathrm{~mm}( \pm 10 \mathrm{~mm})$, a sensitive analyze was performed for preferential infiltration structures (PIS) ranging from 95 to $5 \%$, i.e. AWS ranging from 5 to $145 \mathrm{~mm}$ (increment of $10 \mathrm{~mm}$ ) and surface runoff ranging from 0 to $15 \%$ (increment of $1 \%$ ). The square decreasing sum method showed the best correlation performance $\left(R^{2}\right)$ for both rainfall and effective rainfall and for all sensitive analysis

10 computation. Sensitive analysis shows that a critical AWS threshold of $15 \mathrm{~mm}$ needs to be reached to improve significantly the correlation performance $\left(R^{2}\right.$ superior to median (0.6)) (Fig. 7a). All the best computations have a one day lag. In addition a stage of about 210 days (seasonal variations) seems to explain the best the hydrosystem inertia (Fig. 7b). AWS ranging from 25 (runoff $=3 \%$ ) to $85 \mathrm{~mm}$ (runoff $=9 \%$ ) have an

$15 R^{2}$ superior to 0.6 and a period computation near 210 days, and seems to statistically reflect watershed properties.

The best $R^{2}$ obtained from effective rainfall with homogeneous infiltration assumption $\left(R^{2}=0.572 ; n=75 ; \alpha=0.0434 ; \beta=1 ; \mathrm{PIS}=15 \% ; \mathrm{AWS}=135 \mathrm{~mm}\right.$; runoff $\left.=14 \%\right)$ was far higher than the best obtained with rainfall correlation $\left(R^{2}=0.436 ; n=60\right.$;

$\left.{ }_{20} \alpha=0.0346 ; \beta=1\right)$. In addition the best correlation performance was reached with the effective rainfall with heterogeneous infiltration assumption $\left(R^{2}=0.633 ; n=212\right.$; $\alpha=0.0335 ; \beta=1$; PIS = 85\%; AWS $=25 \mathrm{~mm}$; runoff $=3 \%$ ) (Fig. 7c). Figure 8 shows the weighting factors applied for each day with the square decreasing sum method for the rainfall and effective rainfalls best correlation.

$25 \quad$ Numbers in brackets on Table 4 show the watershed parameters used for this best correlation performance with heterogeneous infiltration assumption (PIS $=85 \%$ ). Figure 9 shows the result relatively to time of cumulative rainfall and effective rainfalls together with detrend A16 displacement.

8971

Heterogeneous infiltration assumption has led to the best correlation performance and show that preferential infiltration structures could gather a large proportion of the flow (until $85 \%$ ) relatively to their watershed surface (15\%). Although A16 displacement is representative of the overall most active zone displacement, it is still a local 5 surface measurement. The sensitive analysis best correlation obtains with $25 \mathrm{~mm}$ could have been influenced by local properties of A16 extensometer. This is why, for further works on Séchilienne, it is recommended to use an AWS from $25 \mathrm{~mm}$ to $85 \mathrm{~mm}$ and a surface runoff from 3 to $9 \%$ according to the purpose of the study.

The weakness of the correlation performance can be explained by the fact that the effective rainfall signal is in turn modified by the aquifer hydrodynamic behavior through hydrosystems transit. In deep seated landslides, displacements are strongly correlated with pore water pressure which is an output of hydrosystems. For this study all the displacements data were correlated not just destabilization stages. Indeed, displacements depend on rock properties and pore water pressure mechanisms which behave differently according to either destabilization or stabilization stages.

\section{Conclusion and perspectives}

This study demonstrated that the displacement data correlation performance is significantly enhanced with effective rainfall compared to results obtained with rainfall only. Most of the landslide sites included weather station(s) with limited meteorological data.

20 A workflow method was developed to compute effective rainfall on a daily interval requiring only temperature and rainfall as input. Two $R_{\mathrm{S}}$ equations and five commonly used $\mathrm{ET}_{0}$ reduced set equations were tested at the Séchilienne site. However, the method was developed to be as unspecific as possible in order to be able to be applicable to other landslides sites.

25 For Séchilienne, $R_{\mathrm{S}}$ equations performances were similar once equations were calibrated and no method was clearly superior to the others. $\mathrm{BC}_{\text {mod }} R_{\mathrm{S}}$ showed the best performance and was selected. $\mathrm{ET}_{0}$ equations performances were acceptable to very 
good. $\mathrm{PM}_{\mathrm{red}} \mathrm{ET}_{0}$ showed the best performance and could work well even without calibration. $\mathrm{PM}_{\text {red }} \mathrm{ET}_{0}$ was used for effective rainfall computation in this study. However, the $\mathrm{HS} \mathrm{ET}_{0}$ method was suggested as an alternative for effortless $\mathrm{ET}_{0}$ estimation. For the Séchilienne site, temperature was missing and had to be estimated, with good per-

5 formance. Temperature estimation brings the worst uncertainties in the estimation of $\mathrm{ET}_{0}$. Fortunately, temperature is commonly measured at weather stations and most of landslide weather stations are equipped. AWS was based on punctual auger holes and then generalized on the whole watershed according to geology/vegetation. A surface runoff was estimated for the whole watershed and was applied only if AWS was

10 fulfilled and daily rainfall was superior than average. Runoff estimation was based on slope/vegetation type only, which allow to take into account a large proportion of it. A sensitive analysis has allowed defining a windowed estimation of AWS (from 25 to $85 \mathrm{~mm}$ ) and of surface runoff (from 3 to $9 \%$ ).

A further step for water budget computation, on the scale of water catchment, will 15 be to account for the spatial and temporal variability of rainfall/snow and AWS, which will allow better estimation of the effective rainfall. Also, consideration of the watershed variability of surface runoff and AWS would be relevant to increasing the accuracy of the estimation.

Assumptions made for effective rainfall calculation were possible because this study 20 took an interest in the appropriate input signal for landslide surveys. Otherwise in case of water budget computation, these could lead to significant computation error.

Effective rainfall enhances the understanding of the relationship between displacement and the rainfall signal. The proposed method for estimation of effective rainfall was developed to be sufficiently simple to be used by any non hydro specialist who takes interest in the characterization of the relationship rainfall-landslide displacements.

Acknowledgements. This research was fund by the program SLAMS (Séchilienne Land movement: Multidisciplinary Studies) of the Agence Nationale de la Recherche. The meteorological data used were provided by MétéoFrance, LTHE, EdF and CETE Lyon. Aerial photography and digital elevation model were provided by Institut national de l'information géographique

8973

et forestière (IGN). Displacement data were supplied by CETE Lyon. The authors gratefully acknowledge the support of Jean-Pierre Duranthon and Marie-Aurélie Chanut from the CETE Lyon and Jean-Paul Laurent from the LTHE. Appreciation is also given to Eric Lucot of ChronoEnvironnement for his kind advises for soil log interpretation. The authors also thank Nick Coffey 5 for English proofreading.

\section{References}

Alexandris, S., Stricevic, R., and Petkovic, S.: Comparative analysis of reference evapotranspiration from the surface of rainfed grass in central Serbia, calculated with six empirical methods against the Penman-Monteith formula, European Water, 21/22, 17-28, 2008.

10 Alfonsi, P.: Relation entre les paramètres hydrologiques et la vitesse dans les glissements de terrains. Exemples de La Clapière et de Séchilienne, Revue française de géotechnique, 79, 3-12, 1997.

Allen, R. E., Pereira, L. S., Raes, D., and Smith, M.: Crop evapotranspiration: guidelines for computing crop water requirements, FAO Irrigation and drainage paper 56, Food and Agriculture Organization of the United Nations, Rome, 1998.

Allen, R. G., Smith, M., Pereira, L. S., and Perrier, A.: An update for the definition of reference evapotranspiration, J. ICID, 43, 1-34, 1994.

Almorox, J.: Estimating global solar radiation from common meteorological data in Aranjuez, Spain, Turk. J. Phys., 35, 53-64, 2011.

20 Binet, S., Mudry, J., Scavia, C., Campus, S., Bertrand, C., and Guglielmi, Y.: In situ characterization of flows in a fractured unstable slope, Geomorphology, 86, 193-203, doi:10.1016/j.geomorph.2006.08.013, 2007.

Bogaard, T., Guglielmi, Y., Marc, V., Emblanch, C., Bertrand, C., and Mudry, J.: Hydrogeochemistry in landslide research: a review, Bulletin de la Societe Geologique de France, 178, 113126, doi:10.2113/gssgfbull.178.2.113, 2007.

Bonzanigo, L., Eberhardt, E., and Loew, S.: Hydromechanical factors controlling the creeping Campo Vallemaggia landslide, in Symposium of landslides, Causes, Impacts and Countermeasures, 17-21 June 2001, Davos, Switzerland, 13-22, 2001. 
Bristow, K. L. and Campbell, G. S.: On the relationship between incoming solar radiation and daily maximum and minimum temperature, Agr. Forest Meteorol., 31, 159-166, doi:10.1016/0168-1923(84)90017-0, 1984.

Bruand, A., Duval, O., and Cousin, I.: Estimation des propriétés de rétention en eau des sols

5 à partir de la base de données SOLHYDRO: Une première proposition combianant le type d'horizon, sa texture et sa densité apparente, Etude et Gestion des Sols, 11, 323-334, 2004.

Canuti, P., Focardi, P., and Garzonio, C.: Correlation between rainfall and landslides, B. Eng. Geol. Environ., 32, 49-54, doi:10.1007/BF02594765, 1985.

Cappa, F., Guglielmi, Y., Rutqvist, J., Tsang, C.-F., and Thoraval, A.: Hydromechanical modelling of pulse tests that measure fluid pressure and fracture normal displacement at the Coaraze Laboratory site, France, Int. J. Rock Mech., 43, 1062-1082, doi:10.1016/j.ijrmms.2006.03.006, 2006.

Castellvi, F.: A new simple method for estimating monthly and daily solar radiation, performance and comparison with other methods at Lleida (NE Spain); a semiarid climate, Theor. Appl. Climatol., 69, 231-238, doi:10.1007/s007040170028, 2001.

Droogers, P. and Allen, R. G.: Estimating reference evapotranspiration under inaccurate data conditions, Irrig. Drain. Syst., 16, 33-45, doi:10.1023/A:1015508322413, 2002.

Duranthon, J.-P., Effendiantz, L., Memier, M., and Previtali, I.: Apport des méthodes topographiques et topométriques au suivi du versant rocheux instable des ruines de Séchilienne, $X Y Z, 94,31-38,2003$.

Durville, J.-L., Kasperki, J., and Duranthon, J.-P.: The Séchilienne landslide: monitoring and kinematics, in: First Italian Workshop on Landslides, 8 June 2009, Napoli, Italia, 2009.

Garel, E., Marc, V., Ruy, S., Cognard-Plancq, A.-L., Klotz, S., Emblanch, C., and Simler, R.: Large scale rainfall simulation to investigate infiltration processes in a small landslide under dry initial conditions: the Draix hillslope experiment, Hydrol. Process., 26, 2171-2186, doi:10.1002/hyp.9273, 2012.

Guglielmi, Y., Vengeon, J. M., Bertrand, C., Mudry, J., Follacci, J. P., and Giraud, A.: Hydrogeochemistry: an investigation tool to evaluate infiltration into large moving rock masses (case study of La Clapière and Séchilienne alpine landslides), B. Eng. Geol. Environ., 61, 311-324, 2002.

Guglielmi, Y., Cappa, F., and Binet, S.: Coupling between hydrogeology and deformation of mountainous rock slopes: Insights from La Clapière area (southern Alps, France), Comptes Rendus Geoscience, 337, 1154-1163, doi:10.1016/j.crte.2005.04.016, 2005.

8975

Hargreaves, G. and Samani, Z.: Reference crop evapotranspiration from temperature, Appl. Eng. Agric., 1, 96-99, 1985.

Helmstetter, A. and Garambois, S.: Seismic monitoring of Séchilienne rockslide (French Alps): Analysis of seismic signals and their correlation with rainfalls, J. Geophys. Res., 115, F03016, doi:10.1029/2009JF001532, 2010.

Hong, Y., Hiura, H., Shino, K., Sassa, K., Suemine, A., Fukuoka, H., and Wang, G.: The influence of intense rainfall on the activity of large-scale crystalline schist landslides in Shikoku Island, Japan, Landslides, 2, 97-105, doi:10.1007/s10346-004-0043-z, 2005.

Igbadun, H., Mahoo, H., Tarimo, A., and Salim, B.: Performance of Two Temperature-Based Reference Evapotranspiration Models in the Mkoji Sub-Catchment in Tanzania, Agricultural Engineering International: the CIGR Ejournal, http://ecommons.library.cornell.edu/handl/1813/ 10573, last access: July 2013, VIII, 2006.

Itenfisu, D., Elliott, R. L., Allen, R. G., and Walter, I. A.: Comparison of reference evapotranspiration calculations as part of the ASCE standardization effort, J. Irrig. Drain. Eng., 129, 440-448, doi:10.1061/(ASCE)0733-9437(2003)129:6(440), 2003.

Jamagne, M., Bétrémieux, R., Bégon, J. C., and Mori, A.: Quelques données sur la variabilité dans le milieu naturel de la réserve en eau des sols, Bull. Tech. Information du Min. de l'Agriculture, 324-325, 627-641, 1977.

Jensen, M. E., Burman, R. D., and Allen, R. G.: Evapotranspiration and irrigation water requirements: a manual, American Society of Civil Engineers, New York, 1990.

Le Roux, O., Jongmans, D., Kasperski, J., Schwartz, S., Potherat, P., Lebrouc, V., Lagabrielle, R., and Meric, O.: Deep geophysical investigation of the large Séchilienne landslide (Western Alps, France) and calibration with geological data, Eng. Geol., 120, 18-31, doi:10.1016/j.enggeo.2011.03.004, 2011.

25 Meric, O., Garambois, S., and Orengo, Y.: Large Gravitational Movement Monitoring Using a Spontaneous Potential Network, in Proc. 19th Annual Symposium on the Application of Geophysics to Engineering and Environmental Problems (SAGEEP), EEGS, 2-6 April 2006, Seattle, USA, 202-209, 2006.

Noverraz, F., Bonnard, C., Dupraz, H., and Huguenin, L.: Grands glissements de terrain et

30 climat, VERSINCLIM - Comportement passé, présent et futur des grands versants instables subactifs en fonction de l'évolution climatique, et évolution en continu des mouvements en profondeur, Rapport final PNR31 (Programme National de Recherche), vdf Hochschulverlag AG an der ETH Zürich, Zürich, Switzerland, 1998. 
Patwardhan, A., Nieber, J., and Johns, E.: Effective rainfall estimation methods, J. Irrig. Drain. Eng., 116, 182-193, doi:10.1061/(ASCE)0733-9437(1990)116:2(182), 1990.

Pisani, G., Castelli, M., and Scavia, C.: Hydrogeological model and hydraulic behaviour of a large landslide in the Italian Western Alps, Nat. Hazards Earth Syst. Sci., 10, 2391-2406, doi:10.5194/nhess-10-2391-2010, 2010.

Rochet, L., Giraud, A., Antoine, P., and Évrard, H.: La déformation du versant sud du montsec dans le secteur des ruines de Séchilienne (Isère), B. Int. Assoc. Eng. Geol., 50, 75-87, doi:10.1007/BF02594959, 1994.

Rutqvist, J. and Stephansson, O.: The role of hydromechanical coupling in fractured rock engineering, Hydrogeol. J., 11, 7-40, doi:10.1007/s10040-002-0241-5, 2003.

Samani, Z.: Estimating solar radiation and evapotranspiration using minimum climatological data, J. Irrigat. Drain. Eng., 126, 265-267, doi:10.1061/(ASCE)0733-9437(2000)126:4(265), 2000.

Sautier, J. L.: Guide du Service Fédéral d'Améliorations Foncières, Confédération Helvétique,

15 http://echo2.epfl.ch/e-drologie/chapitres/chapitre2/chapitre2.html (last access: July 2013), 1984.

Shahidian, S., Serralheiro, R., Serrano, J., Teixeira, J., Haie, N., and Santos, F.: Hargreaves and other reduced-set methods for calculating evapotranspiration, in: Evapotranspiration Remote Sensing and Modeling, edited by: Irmak, A., InTech, doi:10.5772/18059, 2012.

20 Tabari, H. and Talaee, P. H.: Local calibration of the hargreaves and Priestley-Taylor Equations for estimating reference evapotranspiration in arid and cold climates of iran based on the Penman-Monteith Model, J. Hydrol. Eng.-ASCE, 16, 837-845, doi:10.1061/(ASCE)HE.19435584.0000366, 2011.

Tabari, H., Grismer, M. E., and Trajkovic, S.: Comparative analysis of 31 reference evapotranspiration methods under humid conditions, Irrig. Sci., 31, 107-117, doi:10.1007/s00271-0110295-z, 2011.

Trajkovic, S.: Temperature-based approaches for estimating reference evapotranspiration, J. Irrigat. Drain. Eng., 131, 316-323, doi:10.1061/(ASCE)0733-9437(2005)131:4(316), 2005.

Trajkovic, S.: Hargreaves versus Penman-Monteith under humid conditions, J. Irrigat. Drain. Eng., 133, 38-42, doi:10.1061/(ASCE)0733-9437(2007)133:1(38), 2007.

Trajkovic, S. and Stojnic, V.: Effect of wind speed on accuracy of Turc method in a humid climate, Facta universitatis - Series: Architecture and Civil Engineering, 5, 107-113, doi:10.2298/FUACE0702107T, 2007.

8977

Vengeon, J.-M.: Déformation et rupture des versants en terrain métamorphique anisotrope: Apport de l'étude des Ruines de Séchilienne, Ph. D. thesis, Université Joseph Fourrier I, Grenoble, France, 1998.

Yoder, R. E., Odhiambo, L. O., and Wright, W. C.: Evaluation of methods for estimating daily 5 reference crop evapotranspiration at a site in the humid Southeast United States, Appl. Eng. Agr., 21, 197-202, 2005.

Zêzere, J. L., Trigo, R. M., and Trigo, I. F.: Shallow and deep landslides induced by rainfall in the Lisbon region (Portugal): assessment of relationships with the North Atlantic Oscillation, Nat. Hazards Earth Syst. Sci., 5, 331-344, doi:10.5194/nhess-5-331-2005, 2005. 
Table 1. Summary of dataset used for this study with parameters recorded $(\circ)$ and used $(\bullet)$ at each location; Distance (distance from site); $R_{\mathrm{S}}$ (short wave radiation), $N$ (duration of sunshine); $W$ (wind speed); $H$ (humidity); $T$ (temperature); $P$ (precipitation); $D$ (landslide displacement).

\begin{tabular}{|c|c|c|c|c|c|c|c|c|c|c|c|c|}
\hline Station Name & Elevation (m a.s.l.) & Distance $(\mathrm{km})$ & From & To & $\mathrm{R}_{\mathrm{S}}$ & $\mathrm{N}$ & W & $\mathrm{H}$ & T & $\mathrm{P}$ & D & day with data \\
\hline Saint Jean-Saint Nicolas & 1210 & 55 & 1 Jan 2004 & 1 Jan 2012 & - & - & • & - & - & 。 & & 2876 \\
\hline Saint Michel Maur & 698 & 54 & 1 Jan 2004 & 1 Jan 2012 & & - & - & - & - & 。 & & 2864 \\
\hline Grenoble Saint Geoirs & 384 & 51 & 8 Jul 2009 & 1 Jan 2012 & - & - & - & - & - & 。 & & 907 \\
\hline Chamrousse & 1730 & 9 & 12 Sep 2002 & 1 Mar 2012 & & & - & - & 。 & 。 & & 3261 \\
\hline Mont Falcon & 420 & 2 & 14 Sep 2004 & 2 Jul 2012 & & & 。 & 。 & - & 。 & & 2803 \\
\hline Luitel & 1277 & 4 & 6 Jul 2006 & 2 Jul 2012 & & & & & - & & & 2127 \\
\hline Mont Sec & 1148 & 0.2 & 14 Sep 2004 & 2 Jul 2012 & & & & & & - & & 2849 \\
\hline A16 & - & 0 & 1 Jan 1999 & 28 Feb 2012 & & & & & & & - & 4493 \\
\hline
\end{tabular}

8979

Table 2. $R_{\mathrm{S}}$ (short wave radiation) methods: calibration results and performance assessment parameters. Calibration results and performance parameters are the average of these computed at each of three weather stations. With $A, B, C$ and $D$ calibration coefficients, $\alpha$ cloud cover adjustment factor, $R^{2}$ coefficient of determination of linear regression between measured and estimated $R_{\mathrm{S}}$, and RE the relative error.

\begin{tabular}{lccccccc}
\hline Method & $A$ & $B$ & $C$ & $D$ & $\alpha$ & $R^{2}$ & $\mathrm{RE}$ \\
\hline $\mathrm{HS}_{\text {mod }} R_{\mathrm{s}}$ & 0.106 & 0.662 & 0.670 & - & 0.740 & 0.847 & 0.123 \\
$\mathrm{BC}_{\text {mod }} R_{\mathrm{s}}$ & 0.669 & 0.010 & 2.056 & 1.733 & 0.790 & 0.864 & 0.119 \\
\hline
\end{tabular}


Table 3. $\mathrm{ET}_{0}$ (reference crop evapotranspiration) methods: calibration results and performance assessment parameters. Calibration results and performance parameters are the average of these computed at each of three weather stations used. With $a, b, R^{2}$ results of linear regression between $\mathrm{ET}_{0}$ measured and estimated, and $\mathrm{RE}$ the relative error.

\begin{tabular}{lcrcc}
\hline Method & $a$ & $b$ & $R^{2}$ & RE \\
\hline HS Et $_{0}$ & 0.920 & 0.130 & 0.917 & 0.24 \\
Turc ET & 0.880 & 0.434 & 0.900 & 0.257 \\
PT ET $_{0}$ & 0.352 & 0.365 & 0.919 & 0.231 \\
MET $_{0}$ & 1.107 & -0.018 & 0.910 & 0.246 \\
PM $_{\text {red }} \mathrm{ET}_{0}$ & 0.994 & 0.013 & 0.932 & 0.221 \\
\hline
\end{tabular}

8981

Table 4. AWS (soil available water storage) and runoff estimation for Séchilienne unstable slope watershed. With Geology watershed surface proportion of geology type relatively to the watershed, Vegetation watershed surface proportion of vegetation type relatively to the watershed, Average slope the average slope for each vegetation type on the watershed, Runoff the runoff coefficients deduced from slope magnitude and vegetation type, AWS the AWS deduced from auger cores, AWS watershed and Runoff watershed, the AWS and runoff coefficients integrated on the scale of watershed. Whole watershed line is the summary for the entire watershed. The numbers in brackets refer to preferential infiltration structures (PIS) rise up to $85 \%$ of the watershed in order to take into account heterogeneous spatial distribution of infiltration.

\begin{tabular}{|c|c|c|c|c|c|c|c|}
\hline Geology & $\begin{array}{l}\text { Geology wa- } \\
\text { tershed (\%) }\end{array}$ & $\begin{array}{l}\text { Vegetation } \\
\text { watershed } \\
(\%)\end{array}$ & $\begin{array}{l}\text { Average } \\
\text { Slope ( }\left({ }^{\circ}\right)\end{array}$ & Runoff (\%) & $\begin{array}{l}\text { Runoff water- } \\
\text { shed }\end{array}$ & AWS (mm) & $\begin{array}{l}\text { AWS water- } \\
\text { shed }(\mathrm{mm})\end{array}$ \\
\hline Mica-schist & $4(1)$ & & 15.0 & 0.2 & $0.05(0.01)$ & 173 & $7(1)$ \\
\hline Sedimentary & $6(1)$ & Grass 20 (4) & & & & 100 & $6(1)$ \\
\hline Superficial formations & 11 (2) & & & & & 112 & $12(2)$ \\
\hline Mica-schist & $22(4)$ & & 21.0 & 0.1 & $0.09(0.02)$ & 254 & $56(10)$ \\
\hline Sedimentary & $7(1)$ & Forest 65 & & & & 81 & $6(1)$ \\
\hline Superficial formations & $35(6)$ & & & & & 133 & $47(8)$ \\
\hline & $15(85)$ & None 15 (85) & $\begin{array}{l}\text { Direct infiltra- } \\
\text { tion }\end{array}$ & 0 & $0(0)$ & 0 & $0(0)$ \\
\hline Whole watershed & $100(100)$ & - & - & - & $0.14(0.03)$ & - & $133(24)$ \\
\hline
\end{tabular}




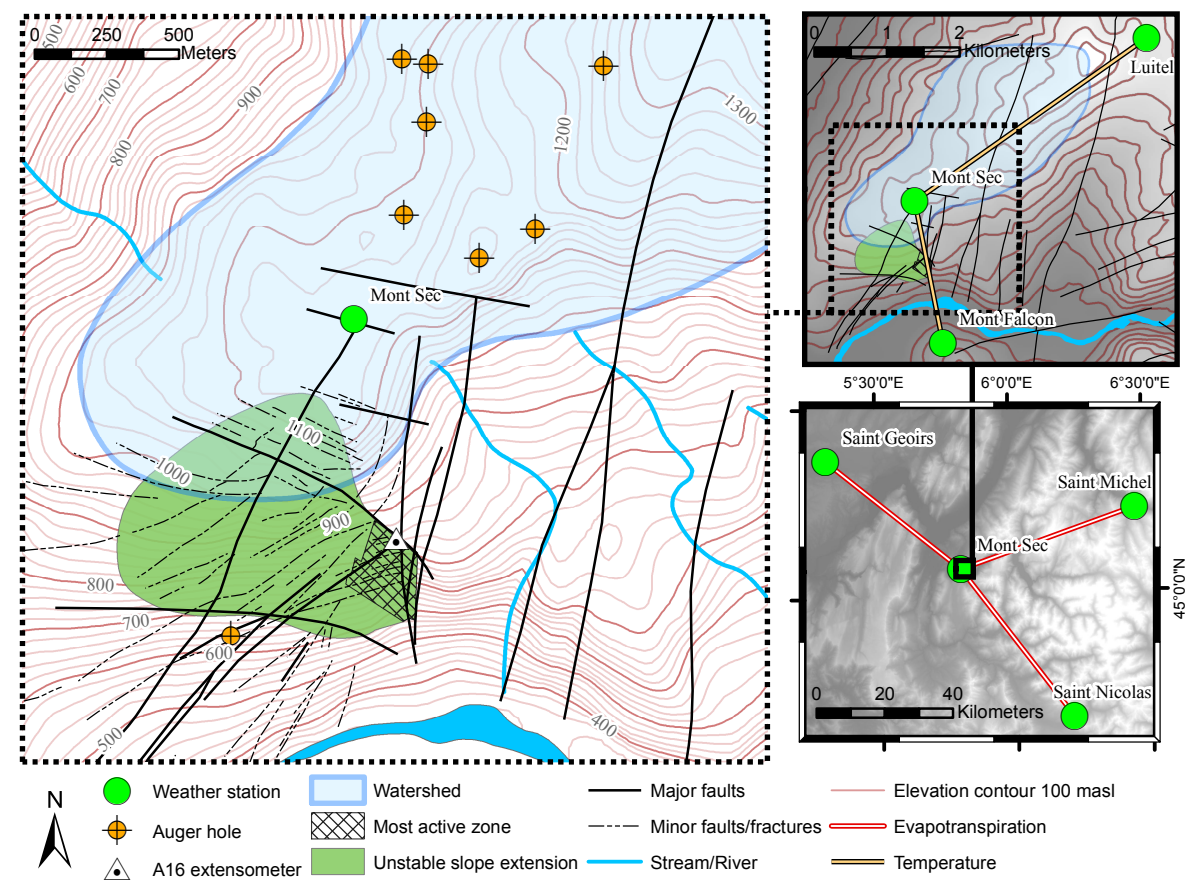

Fig. 1. Site map.

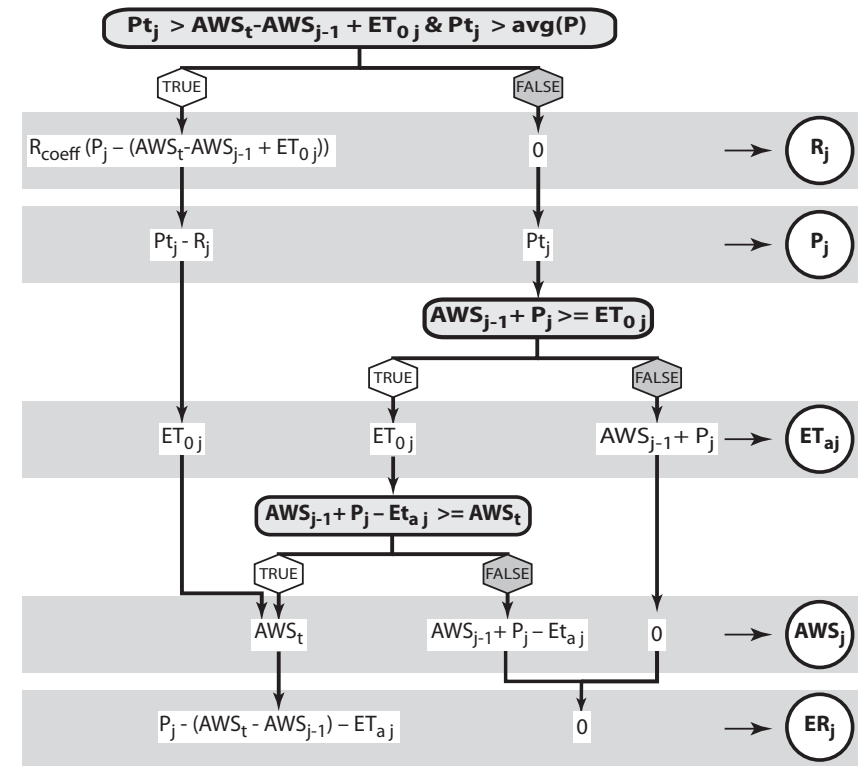

Fig. 2. Soil-water balance workflow for effective rainfall computation on a daily interval. Interception was disregarded. AWS is the soil available water storage, $\mathrm{Pt}$ is the total precipitation (rainfall + snow melt), avg $(P)$ is the precipitation average of the entire dataset, $P$ is the precipitation which infiltrates the soil layer, $R$ is runoff, $R_{\text {coeff }}$ is runoff coefficient, $\mathrm{ET}_{0}$ is the reference crop evapotranspiration, $\mathrm{ET}_{\mathrm{a}}$ is the actual crop evapotranspiration, and ER is the effective rainfall. All previously cited parameter units are $\mathrm{mm}$ of water apart from $R_{\text {coeff }} . j$ is the computation day and $j-1$ is the day before. TRUE and FALSE are the answers of the conditional inequality statements. 


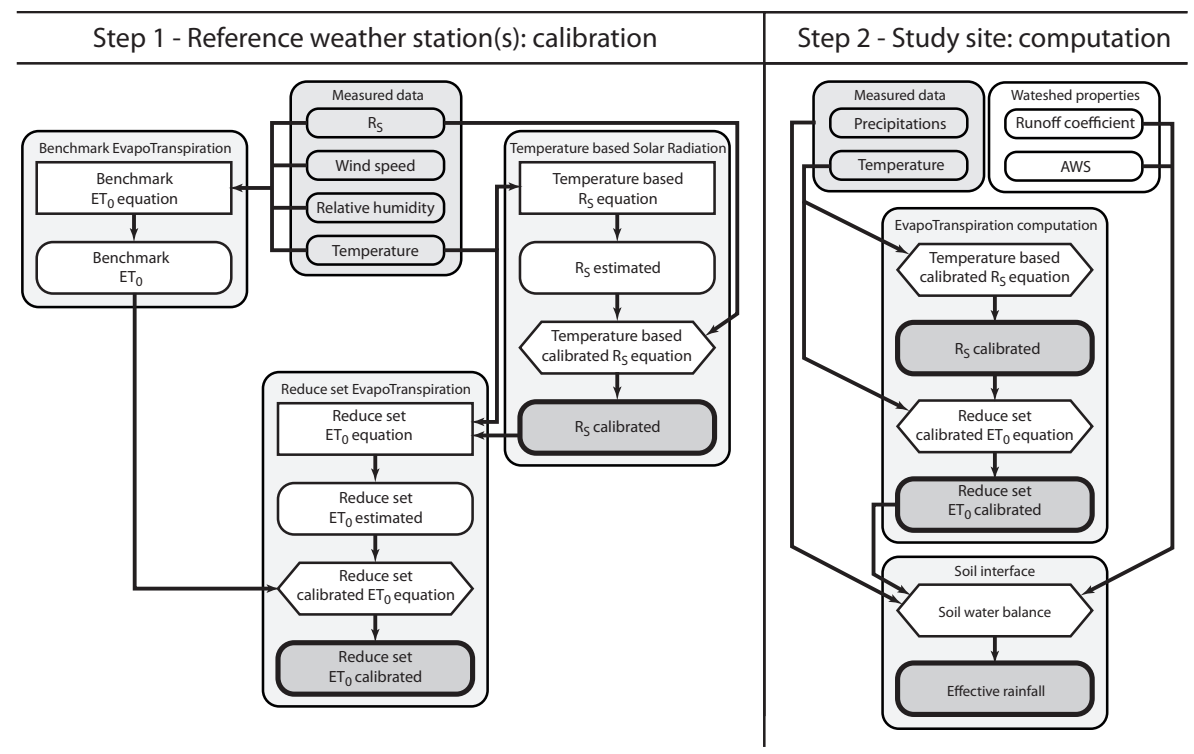

Fig. 3. Effective rainfall method workflow; step 1 calibration of standard $\mathrm{ET}_{0}$ (reference crop evapotranspiration) and $R_{\mathrm{S}}$ (short wave radiation) equations; step 2 computation of effective rainfall on site with calibrated equations and AWS (soil available water storage) estimation. Reference $\mathrm{ET}_{0}$ equation matches with Penman-Monteith equation defined in the FAO-56 paper and reduced set $\mathrm{ET}_{0}$ equation with $\mathrm{ET}_{0}$ equations requiring minimal meteorological data inputs.
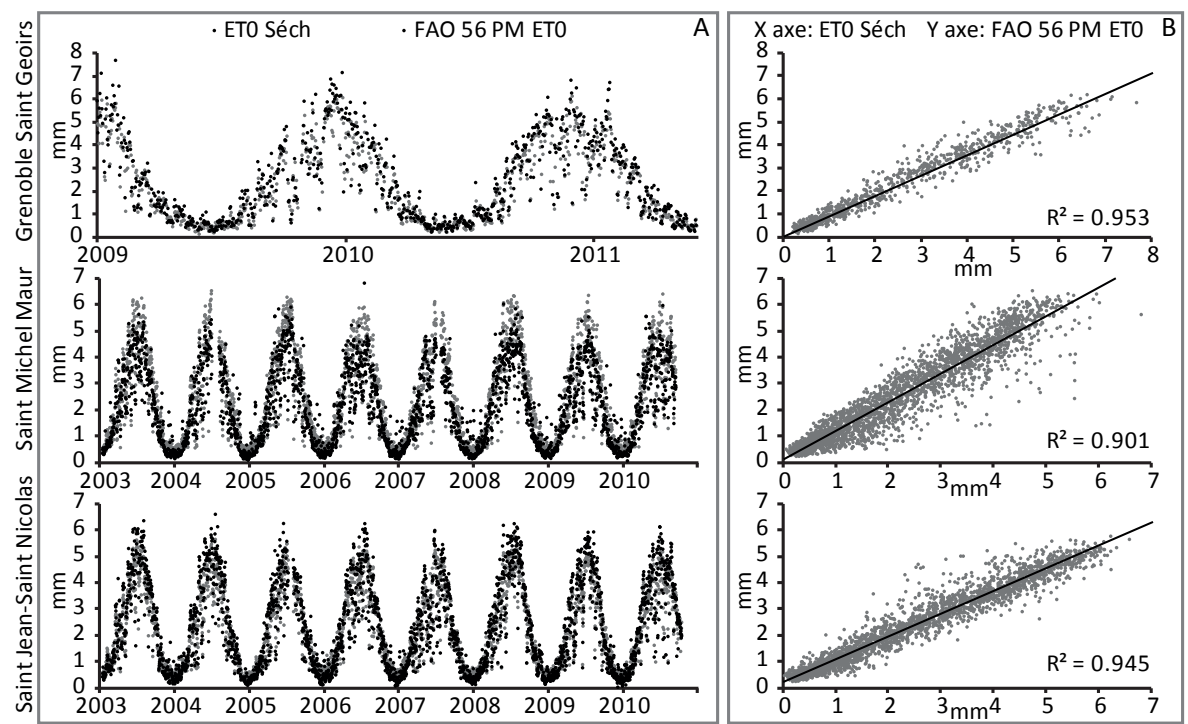

Fig. 4. $\mathrm{ET}_{0}$ (reference crop evapotranspiration) regional calibration results at the three reference weather stations (Grenoble Saint Geoirs, Saint Jean-Saint Nicolas, Saint Michel-Maur) with (A): $\mathrm{ET}_{0}$ Séch and $\mathrm{FAO}-56 \mathrm{PM} \mathrm{ET}_{0}$ function of time; (B): linear regression between $\mathrm{ET}_{0}$ Séch (X-axis) and FAO-56 PM ET (Y-axis). FAO-56 PM ET $\mathrm{PT}_{0}$ is the $\mathrm{ET}_{0}$ computed with PenmanMonteith equation defined in the FAO-56 paper. $\mathrm{ET}_{0}$ Séch is the $\mathrm{ET}_{0}$ computed with the combination of both calibrated equations: $\mathrm{ET}_{0}$ Penman-Monteith reduced set equation and $R_{\mathrm{S}}$ (short wave radiation) modified Bristow-Campbell equation. 


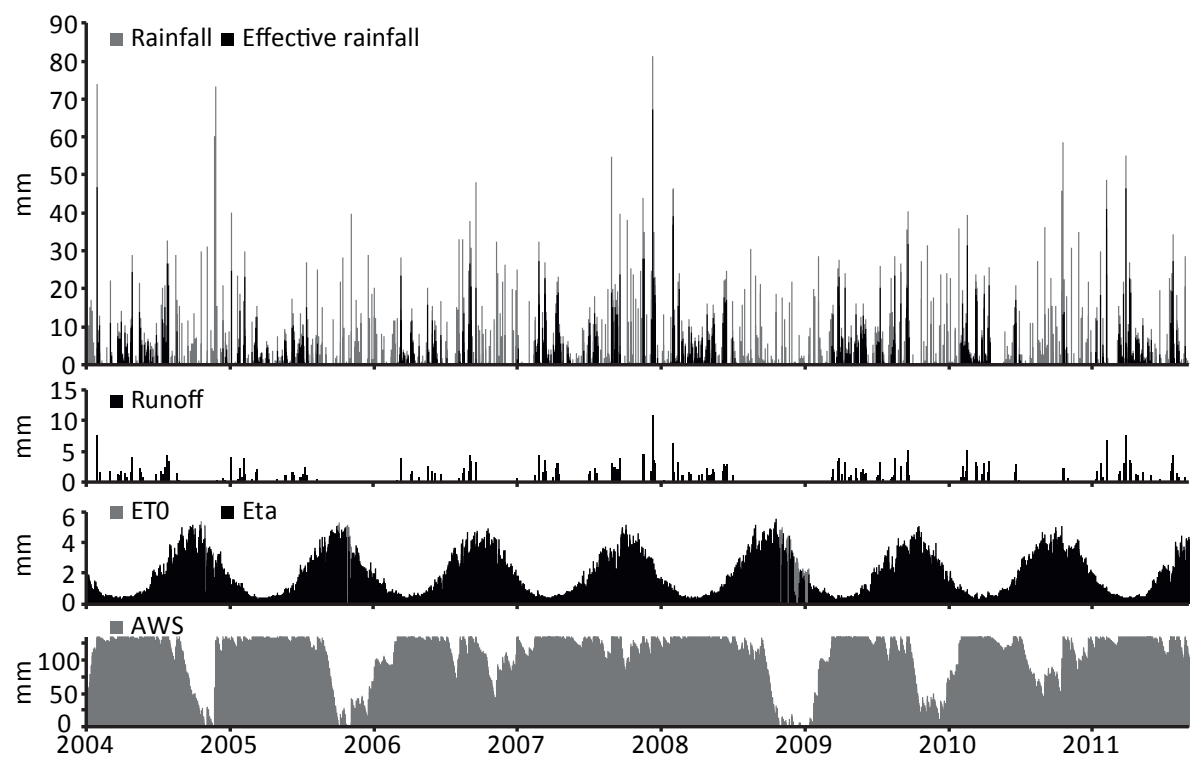

Fig. 5. Results of effective rainfall computation at Séchilienne site. With $\mathrm{ET}_{0}$ (reference crop evapotranspiration), $\mathrm{ET}_{\mathrm{a}}$ (actual crop evapotranspiration) and AWS (soil available water storage).

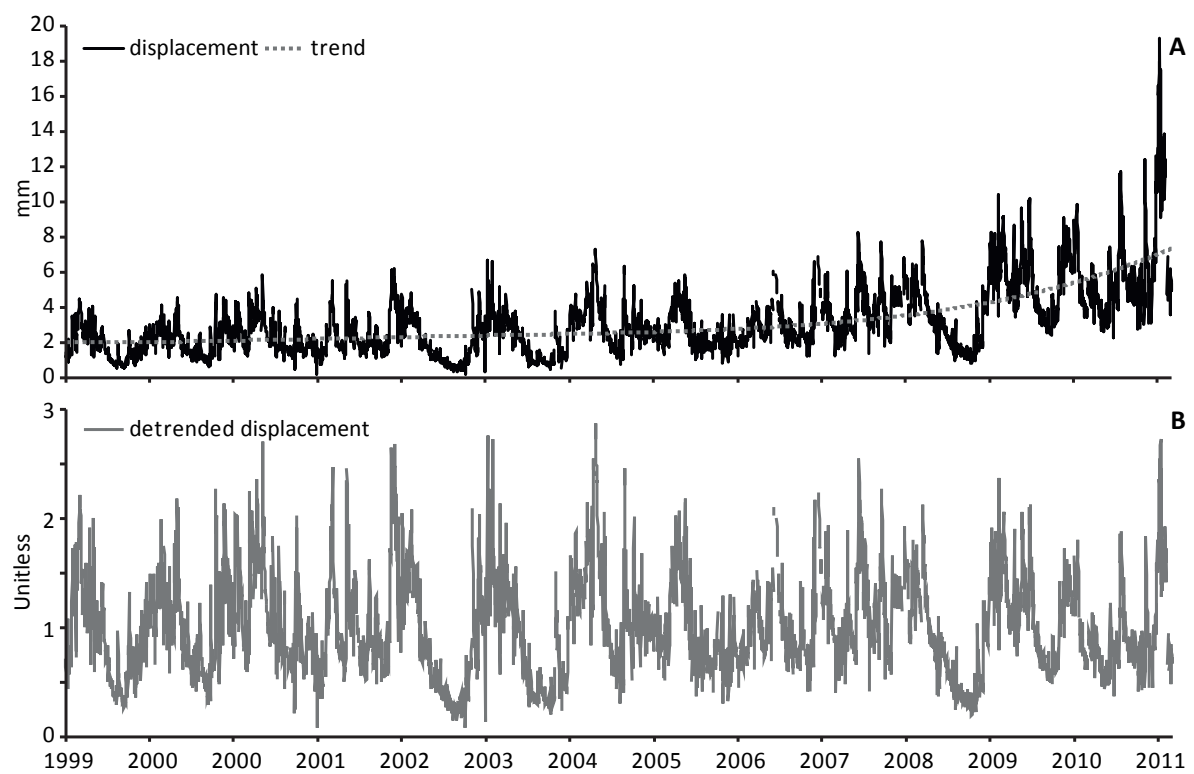

Fig. 6. Results of trend removal of A16 displacement data with (A): A16 displacement data and fourth order polynomial curve fitting assumed as trend; (B): A16 detrended data (unitless) which correspond to A16 displacement data of which trend was removed by multiplicative method. 


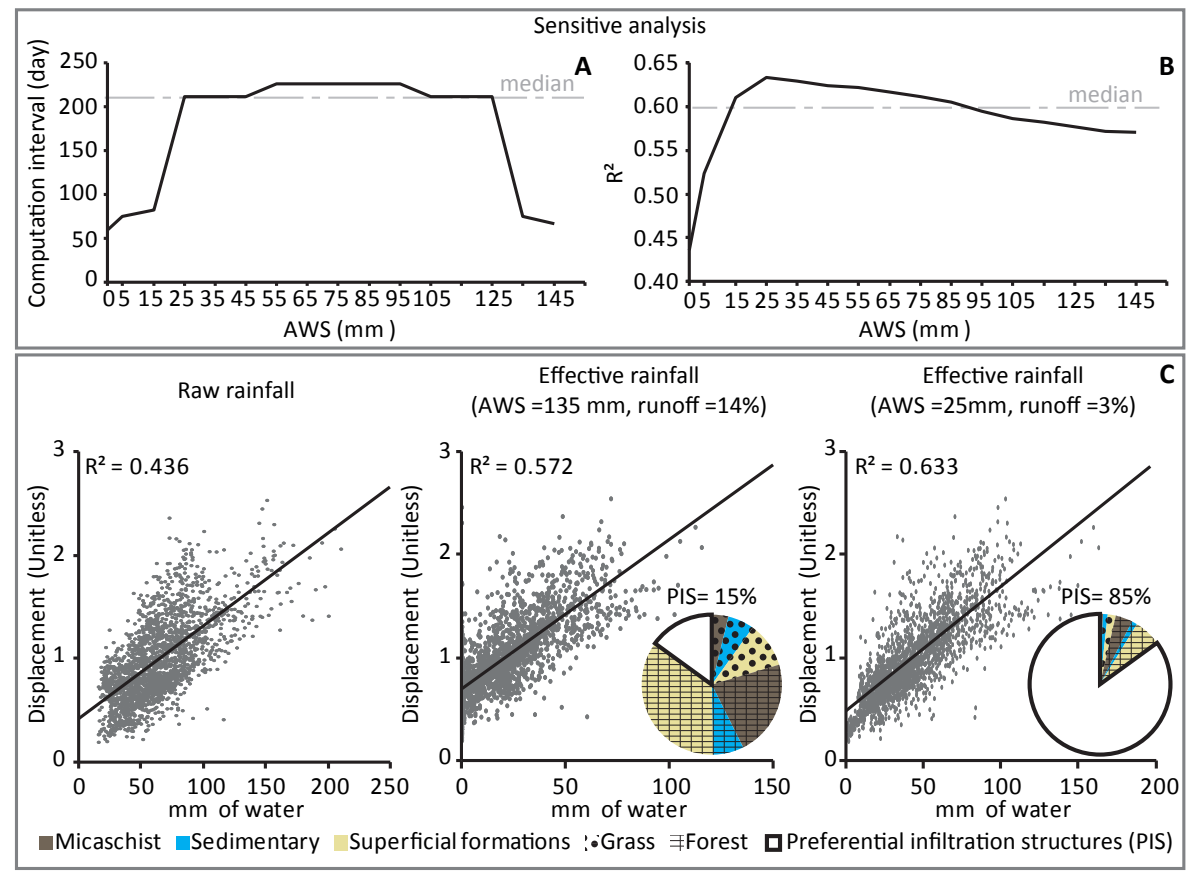

Fig. 7. Result of sensitive analysis (A and $\mathbf{B})$ and best linear regression between raw rainfall/effective rainfall and $\mathrm{A} 16$ detrended displacement (C).

8989

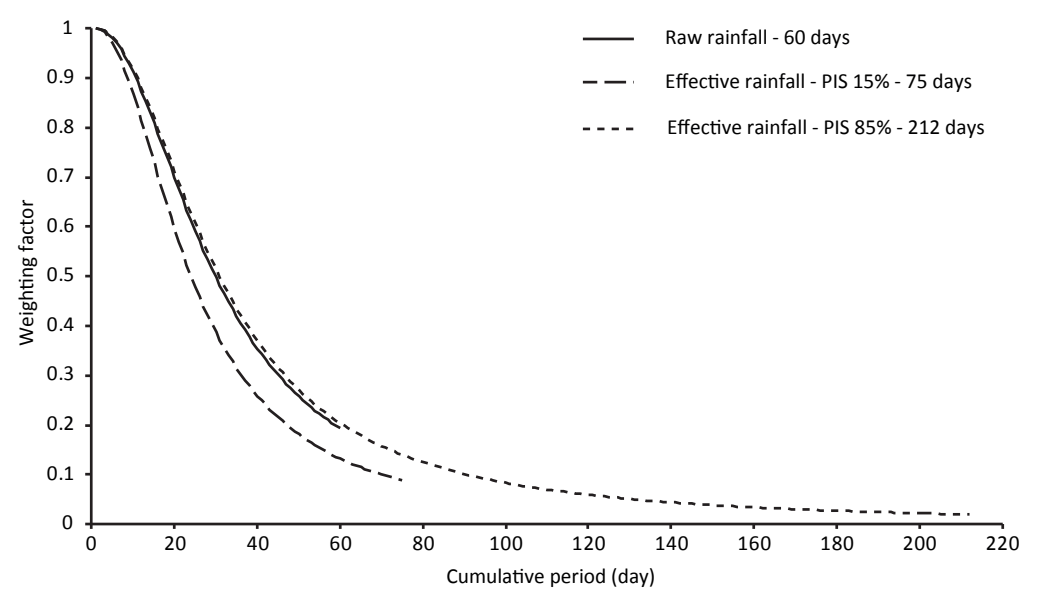

Fig. 8. Summary of weighting factors applied to rainfall and effective rainfall best correlation with A16 detrended displacement. PIS stands for preferential infiltration structures and number of days matches with the cumulative period. 


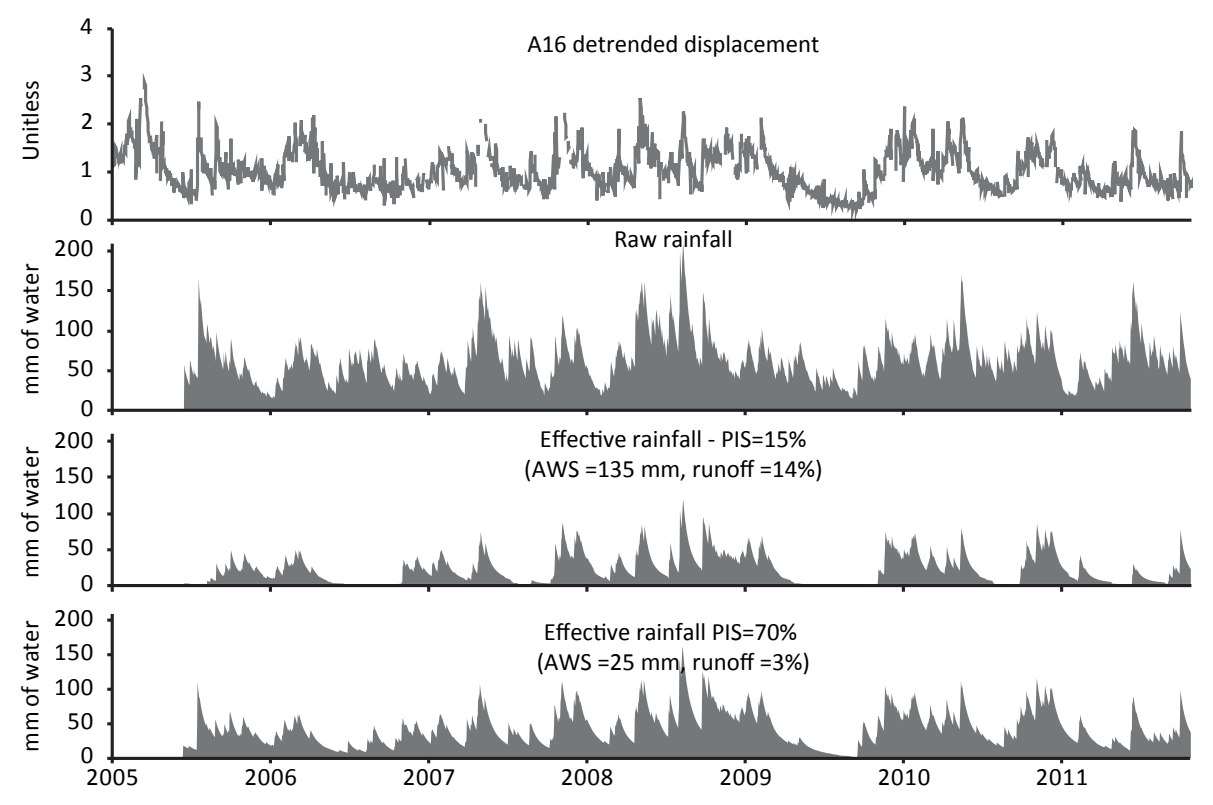

Fig. 9. Result of best correlation between effective rainfall/rainfall and A16 detrended displacement. With PIS the preferential infiltration structures, AWS the soil available water storage. 